\title{
The Values of Versatility: Pharmacists, Plants, and Place in the French (Post)Colonial World
}

\author{
LAURENCE MONNAIS \\ Département d'histoire, Canada Research Chair in Healthcare Pluralism, \\ Université de Montréal
}

\section{NOÉMI TOUSIGNANT}

\author{
Département d'histoire, Université de Montréal and Department of Social \\ Studies of Medicine, McGill University
}

Pharmacists were key players in harnessing the therapeutic and medicinal values of plants in the French colonies. They bio-prospected, acclimatized, chemically screened, and tinkered with plants and their parts, hoping to create products to supply colonial public health efforts, metropolitan industries, and imperial markets. Among these pharmacists was Franck Guichard (18941971), who became in 1939 the first director of the Laboratory for the Study of Indochinese Materia Medica in Hanoi, French Indochina. Another was Joseph Kerharo (1909-1986), who in 1945 was assigned to a major mission to prospect for medicinal plants in the colony of Côte d'Ivoire, in French West Africa (Afrique occidentale française, AOF) by the Office of Colonial Scientific Research (Office de la recherche scientifique coloniale, ORSC). Both Guichard and Kerharo studied medicinal plants as part of their duties as officers of the French colonial health corps. Yet their interest in indigenous therapies exceeded and outlived the colonial projects that sparked it. Taking this "overflow" as its point of departure, this article explores the transformation of medicinal plant value by science in colonial and postcolonial contexts. Our focus is on the relationship between value and space; that is, on the processes of conceptual and material (de-/re-)localization through which plant value is calculated,

\footnotetext{
Acknowledgments: We gratefully acknowledge support for this article from the Social Sciences and Humanities Research Council of Canada (SSHRC), as well as the Economic and Social Research Council (ESRC, RES-360-25-0032), and the Leverhulme Trust (F/02 116D). All translations from French and Vietnamese are our own.
} 
intensified, and distributed. We study these processes from French Indochina and AOF, and the nation-states of Vietnam and Senegal, where Guichard and Kerharo engaged in them most intensively. ${ }^{1}$

Attending to the spatial dynamics of value prompts questions about who controls, benefits from, and is given credit in medicinal plant research. Modes of research that extract plants as raw resources under relations of global domination, exporting value while jettisoning indigenous histories, epistemologies, and technologies, are often characterized as "extractive" and thus (neo)colonial. The localization of indigenous plant therapies as national or ethnic resources, cultural heritage, and "appropriate technology" is instead associated with "neo-traditionalist" postcolonial nationalist projects. Guichard and Kerharo, however, participated in projects that can be clearly identified as either extractive or neo-traditionalist, and their trajectories through medicinal plant research are made up of dynamic positions within multiple, shifting networks of knowledge and material exchange. These were colonial, but also imperial, international, and postcolonial, as well as scientific and personal. As Guichard's and Kerharo's own professional biographies overflowed specific politico-economic medicinal plant projects, they also enacted and imagined geographies of value that overflowed the categories of extractive and neo-traditionalist. By following their trajectories of expertise, rather than the trajectories of plants or the unfolding of specific projects, we can illuminate the complexity of the spatial, political, and economic dynamics of colonial science and of medicinal plant science under and after colonial rule. To capture this complexity, in which science is instrumentalized to serve colonialism, nationalism, and capitalism, but is also shaped by variegated professional and ethical commitments to knowledge, people, and value, we propose an analysis focusing on the "circulatory politics" of (post)colonial science.

\section{(RE)LOCATING PLANT VALUE IN PHARMACISTS' TRAJECTORIES}

\section{Plants, Science, Mobility, and "the Local"}

The large-scale movement of plant matter has over centuries transformed natural knowledge, commercial exchange, therapeutics, and ecologies. ${ }^{2}$ To

\footnotetext{
1 Indochina was a colonial territory headed by a governor general in Hanoi and made up of five territorial entities (pays) from 1887 to the end of the Indochina War of independence (1954): a colony, Cochinchina (Southern Vietnam), and four protectorates Annam (central Vietnam), Tonkin (northern Vietnam), Cambodia and Laos. AOF (1895-1958) was a federation headed by a governor general that grouped up to eight French colonies in Western Africa: Senegal, French Sudan, Mauritania, Côte d'Ivoire, Dahomey, Guinea, Upper Volta, and Niger. From 1902, its capital was Dakar.

2 Robert A. Voeks, "Disturbance Pharmacopoeias: Medicine and Myth from the Humid Tropics," Annals of the Association of American Geographers 94 (2004): 868-88; Harold J. Cook, Matters of Exchange: Commerce, Medicine, and Science in the Dutch Golden Age (New Haven: Yale University Press, 2007); Londa L. Schiebinger, Plants and Empire: Colonial
} 
initiate or accelerate traffic in aromatic, medicinal, and other "useful" plants was part of the aims of European commercial expansion from at least the seventeenth century. ${ }^{3}$ The relocation of plants increased their value for those who controlled the territory in which they might be grown and markets in which they could be sold. As they moved, plants were at least partially severed from local epistemologies, economies, and ecologies.

Science has played a central role in global plant mobility. This role is most often cast as extractive. Londa Schiebinger qualifies botany in the early modern period as both "big science" and "big business" in that it amplified the profit that could be drawn from dominating resource-rich territories. ${ }^{4}$ The advancement of botanical, agronomic, and then pharmacological knowledge was fueled by contact with "exotic" plants, while practices of collection and analysis facilitated the displacement of plant matter from its social and ecological origins - as samples, specimens, seedlings, and commodities, and from the nineteenth century also as active compounds. ${ }^{5}$ Scientists, including pharmacists, inventoried plants as natural resources, identified those that could turn a profit, and worked to make imported species grow within the boundaries of political control. Indeed, Michael Osborne, writing about the nineteenth century, calls "acclimatization" (responding to botanical, zoological, and medical concerns with how to best relocate organisms) "the paradigmatic colonial science." 6 The isolation and extraction of active pharmacological principles from plant matter kindled new interests in colonially sourced plants. ${ }^{7}$ Access to potential plant value still relied on the expertise of colonized populations, but defining efficacy at the level of biochemistry rather than bodily experience relocated the power to measure and intensify value in metropolitan experts, well-equipped laboratories, and pharmaceutical factories. This further centralized, and standardized, the "calculation" of plant value initiated

\footnotetext{
Bioprospecting in the Atlantic World (London: Harvard University Press, 2004); John Merson, "Bio-Prospecting or Bio-Piracy: Intellectual Property Rights and Biodiversity in a Colonial and Postcolonial Context," Osiris 15 (2000): 282-96; Lucile H. Brockway, Science and Colonial Expansion: The Role of the British Royal Botanic Gardens (New York: Academic Press, 1979); Richard Drayton, Nature's Government: Science, Imperial Britain and the 'Improvement' of the World (New Haven: Yale University Press, 2000).

3 Paula De Vos, "The Science of Spices: Empiricism and Economic Botany in the Early Spanish Empire," Journal of World History 17 (2006): 399-427.

4 Schiebinger, Plants and Empire, 5.

5 Abena Dove Osseo-Asare, Bitter Roots: The Search for Healing Plants in Africa (Chicago: University of Chicago Press, 2014).

6 Michael A. Osborne, "Acclimatising the World: A History of the Paradigmatic Colonial Science," Osiris 15 (2000): 135-51.

7 Markku Hokkanen, "Imperial Networks, Colonial Bioprospecting and Burroughs Wellcome \& Co.: The Case of Strophanthus Kombe from Malawi (1859-1915)," Social History of Medicine 25, 3 (2012): 589-607; Osseo-Asare, Bitter Roots; Merson, "Bio-Prospecting."
} 
in European botanical gardens, and thus sharpened a global division of scientific labor and power. ${ }^{8}$

Renewed interest in bio-prospecting from the 1980s (the term, a contraction of "biodiversity prospecting," was coined in 1992) elicited debates about the extraction of value accumulated through indigenous stewardship of ecologies, botanical knowledge, and healing traditions. The Convention on Biodiversity, signed in 1993, was a landmark event in the search for fairer terms of exchange. It shifted jurisdiction over biological resources and associated indigenous knowledge from the global commons to nation-states. ${ }^{9}$ These debates and measures were marked, implicitly and explicitly, by a colonial history of approaching the global commons as "there for the taking" through conquest, domination, and science. ${ }^{10}$ Past medico-botanical exchanges were re-examined as examples of bio-prospecting, notably by Londa Schiebinger, Abena Osseo-Asare, and Marku Hokkanen, and this revealed the effects of imperial power in redefinitions of plant value, identity, and ownership. These cases demonstrate the alienation effected by the selective mobilization of some parts of a plant's properties, and the obscuring or erasure of others, thus denying indigenous knowledge and the importance of locality even while they continued to be relied upon.

Thinking in terms of extraction aligns epistemological, political, and economic regimes of valuation, and foregrounds colonialism as a tool for stabilizing hierarchies of knowledge and giving priority to a certain type of scientist and expert. Yet in supposing a single, unidirectional trajectory of delocalization, extraction can obscure the making and multiplying of localities in the mobilization of plant value, as Abena Osseo-Asare has shown. ${ }^{11}$ Some colonial medicinal plant work, for example, was primarily oriented not toward metropolitan but rather colonial markets, sometimes with minimal metropolitan intervention. While critical approaches to extraction crucially recognize local agency (by tracing its denial), these risk pinning down the "local" as a static container for indigenous histories, technologies, and knowledge. ${ }^{12}$ Agents of plant knowledge act not just in but also on the local. This comes to the fore in ethnographic studies of "benefit-sharing" in the wake of the Convention on Biodiversity. Attempts to trace trajectories that adequately take from and give back to "local communities" come up against contests over who can

\footnotetext{
${ }^{8}$ Pratik Chakrabarty, "Empire and Alternatives: Swietenia Febrifuga and the Cinchona Substitutes," Medical History 54 (2010): 75-94. On botanical gardens, see Brockway, Science; and Drayton, Nature's Government. On centers of calculation, see Bruno Latour, Science in Action: How to Follow Scientists and Engineers through Society (Cambridge: Harvard University Press, 1987).

9 Merson, "Bio-Prospecting"; Cori Hayden, "From Market to Market: Bioprospecting's Idioms of Inclusion," American Ethnologist 30 (2003): 359-71.

${ }^{10}$ Schiebinger, Plants and Empire, 17; Hayden, "From Market to Market," 361.

${ }^{11}$ Osseo-Asare, Bitter Roots.

12 Hughes Raffles, “Intimate Knowledge," International Social Science Journal 54, 173 (2002): 325-35.
} 
speak for communities, as well as between scientific and indigenous modes of attributing value. ${ }^{13}$ Furthermore, the difficulty of mapping plant knowledge and value onto the local also stems, as Cori Hayden points out, from a problematic assumption: that "plants, people and knowledge ... must be found together — localized and localizable —in one discrete package...." ${ }^{14}$ Such localization, Hayden suggests, is not a given but historically contingent, shaped by "struggles over sovereignties and rights and open to debate." The key question, then, is: "In what idiom - territoriality, nationalism, cosmopolitanism, authorshipwill biological collections be attached to social relations, interests and claims?"15

Hayden's question challenges us to consider how plants and therapies have been (re)localized over time. ${ }^{16}$ If scientists were often tasked with universalizing or globalizing the properties of medicinal plants, they were also enrolled in projects to establish the specifically local (national, indigenous, or ethnic) histories and utility of medicinal plants. The latter are usually associated with postcolonial nationalist projects to claim the value of cultural heritage and bolster economic self-sufficiency, which can be labeled neo-traditionalist. ${ }^{17}$ But such projects were foreshadowed by colonial efforts to render "traditional" pharmacopeias locally usable. An example is Vietnam as part of French Indochina in the 1930s, when the colonial administration embarked on an ambitious, but never finished, project to scientifically rationalize the indigenous materia medica. Guichard participated in this project, which sought to cheaply scale-up the provision of primary healthcare by using local products. Yet this initiative also responded to demands from both Vietnamese traditional healers and Vietnamese Western-trained pharmacists looking to legitimize indigenous therapies and assert a genuinely Vietnamese medicine freed of its Chinese lineage. ${ }^{18}$ In West Africa, Kerharo prospected in the late 1940s with

13 Ronald Nigh, "Maya Medicine in the Biological Gaze: Bioprospecting Research as Herbal Fetishism," Current Anthropology 43, 3 (2002): 451-77; Shane Greene, "Indigenous People Incorporated? Culture as Politics, Culture as Property in Pharmaceutical Bioprospecting," Current Anthropology 45 (2004): 211-37.

14 Hayden, "From Market to Market," 362.

15 Ibid., 368.

16 For a relevant analysis of the relation between (re)localization, naming, and historicization, see Projit Bihari Mukharji, "Vishalyakarani as Eupatorium Ayapana: Retro-Botanizing, Embedded Traditions, and Multiple Historicities of Plants in Colonial Bengal, 1890-1940," Journal of Asian Studies 73, 1 (2014): 65-87.

17 For examples, see: Stacey A. Langwick, "Healers and Scientists: The Epistemological Politics of Research about Medicinal Plants in Tanzania," in Wenzel P. Geissler and Catherine Molyneux, eds., Evidence, Ethos and Experiment: The Anthropology and History of Medical Research in Africa (New York: Berghahn Books, 2011), 263-96; Laurence Monnais, C.-Michele Thompson, and Ayo Wahlberg, eds., Southern Medicine for Southern People: Vietnamese Medicine in the Making (Newcastle upon Tyne: Cambridge Scholars Publishing, 2012).

18 On this movement, see Laurence Monnais, "Can Traditional Medicine Be (Scientifically) Trustworthy? Colonial Views of Vietnamese Medicine in the First Half of the Twentieth Century," in Monnais, Thompson, and Wahlberg, Southern Medicine, 61-84. 
a view toward identifying potential value for both colonial revenues and metropolitan science and industry. Yet, after independence, he built directly on this work to produce a "Senegalese" pharmacopeia that valorized local cultural heritage and promoted national self-sufficiency.

Guichard's and Kerharo's trajectories thus connect diverse types of engagement with medicinal plant value within geographically mobile and highly versatile careers. Such careers were typical for pharmacists employed by the colonial health corps. What vantage do such trajectories offer on the practices and stakes - personal, professional, and political — of the (re)making of value and locality of medicinal plants in the French Empire?

\section{The Versatile French Colonial Pharmacist}

The majority of pharmacists working for the French colonial government in Indochina or Senegal were military officers of the colonial health corps (affiliated to the Corps de santé des troupes coloniales from the turn of the twentieth century onward) and functionaries. To join the corps, they competed, from 1890, for a place at the Naval Medical School in Bordeaux after obtaining a state diploma at a Faculty of Pharmacy. Before heading for the colonies, they, like medical officers, underwent an additional eight months of intensive practical training in Marseille at the Pharo, the Applied School of the Colonial Troops, which opened in 1907. Through courses and internships, and at the Institut Pasteur in Paris, pharmacists were taught the chemical analysis of food, biological substances, poisons, and drugs; methods of radiography, bacteriology, and parasitology; and the running of hospital pharmacy and food analysis labs. They were also exposed to general colonial culture through courses at the Marseille Colonial Institute and visits to its Colonial Museum and botanical gardens. ${ }^{19}$

The versatility of colonial pharmacists' training was in part an expression of the versatile expertise acquired by the profession in the metropole. The timeframe of French colonialism (1830s-1960s) coincided with the development of synthetic chemistry, pharmaceutical manufacturing, and public health regulation, including an increasingly dense legislative framework for the preparation and sale of medicinal substances and medicines, especially toxic ones. ${ }^{20}$ Pharmacists benefitted professionally from tighter restrictions on the right to manipulate drugs and gained new opportunities as researchers and regulators. The scientific basis of their qualifications and status was reinforced and they

19 On the general history of colonial pharmacists, see Pierre Pluchon, Histoire des Médecins et des Pharmaciens de la Marine et des Colonies (Toulouse: Privat, 1985); and Jean-Louis Oudart, "Les Pharmaciens Coloniaux," Médecine Tropicale 65 (2005): 265-72.

${ }^{20}$ Laurence Monnais, Médicaments Coloniaux: L'Expérience Vietnamienne, 1905-40 (Paris: Les Indes Savantes, 2014), 56-57. Although pharmaceutical regulation was being tightened across Europe, the French government appears to have been particularly obsessed with this issue, and transferred strict legislation on toxics to its colonies. 
were at the forefront of emerging scientific specializations such as hospital biochemistry and toxicology. ${ }^{21}$ Versatility emerged as a key virtue of the selfimage projected by pharmacists when they celebrated the heroes of their profession. ${ }^{22}$

This versatility was intensified in the colonies, where colonial pharmacists often juggled a variety of administrative, scientific, and technical tasks. This was partly due to chronic staff shortages at different levels: in the health service, in scientific personnel more generally, and especially in the number of pharmacists. In 1890, there were only thirty-four colonial pharmacists in the whole French Empire, and by 1954, after significant investments in technical and scientific staff, there were still just $135 .{ }^{23}$ In Indochina, forty pharmacists were working for the colonial government in 1931 (of which thirty-four were "Indochinese auxiliary pharmacists") while the area's population had probably reached twenty-three million; ten years later, in the vast territory of AOF, there were thirty-nine (fifteen European and twenty-four auxiliary) ${ }^{24}$ Fully qualified pharmacists were only present, and usually part-time, at central nodes of the healthcare system - wholesale supply pharmacies and those of major hospitals - where they oversaw the preparation and distribution of chemicals and pharmaceuticals from bulk ingredients shipped from France.

These jobs made up only a fraction of their official duties, since they were also charged with other jobs, from monitoring food and water quality to overseeing private pharmacy inspections, hospital biology laboratories, medical and pharmacy education, and government control laboratories. They could be called on to work in colonial research institutions such as the Instituts Pasteur d'outre-mer, of which there were four in Indochina and one in Senegal. Pharmacists were often the only experts in chemical analysis and biochemistry in the colonial administration. Another source of demand for pharmacists was the colonial regulation of "traditional" therapies. In Indochina, for example, the application of metropolitan laws on toxic substances to the

21 Claude Dreux, "Hommage à M. L. Girard: Gestation et Naissance de la Biochimie Hospitalière," Revue d'Histoire de la Pharmacie 87, 324 (1999): 425-32; Georges Le Moan, "L'Enseignement de la Toxicologie à Paris dans le Cursus des Etudes Pharmaceutiques," Revue d'Histoire de la Pharmacie 72, 262 (1984): 319-26.

22 Sophie Bréchoteau, Les Pharmaciens et l'Industrie Sucrière aux XVIIIe et XIXe siècles, Doctorat d'état en pharmacie, Université Bordeaux II, 1997; Alex Berman, “J.B.A. Chevallier, Pharmacist-Chemist, a Major Figure in Nineteenth-Century Public Health," Bulletin of the History of Medicine 52 (1978): 200-13; Séverine Baverey-Massat-Bourrat, "De la copie au nouveau médicament: Le Laboratoire de chimie thérapeutique et Rhône-Poulenc: Un réseau alternatif d'innovation," Entreprises et Histoire 36, 2 (2004): 48-63.

23 Oudart, "Les Pharmaciens," 263.

24 Indochinese auxiliary pharmacists were trained at the Faculty of Medicine and Pharmacy in Hanoi from 1917. From 1935, they were able to obtain the full status of pharmacist (with a doctorate) there (Monnais, Médicaments Coloniaux, 155). In AOF, auxiliary pharmacists were trained in Dakar starting in 1919, and were renamed "African pharmacists" in 1949. Until independence, West Africans had to study in France to obtain a full state diploma. 
sale of indigenous therapies created a heavy workload for those in the pharmacy inspection service created in $1908 .^{25}$

Pharmacists' multi-tasking was also fostered by specifically French colonial concerns with mise en valeur (colonial "improvement"), which was increasingly emphasized in colonial policies from the interwar period. Though this ideology was unevenly applied, depending on the means and perceived potential of each colony, it underpinned investments in economic production and social modernization across the empire. ${ }^{26}$ Pharmacists, among others, were expected to contribute to economic rationalization by identifying raw resources that could be transformed into new or replacement products. Especially in response to wartime shortages, the colonies were identified as sources of substitutes for imports to the metropole, but were also called upon to ensure their own self-reliance in the face of insufficient budgets and transport difficulties.

Pharmacists were thus asked by local colonial authorities to inventory and identify a broad range of vegetal and mineral substances with potentials for making food, fuel, paper, medicines, bandages, stimulants, lubricants, or soap. This search sometimes involved onsite laboratory work to analyze and experiment with the properties of local or acclimatized plants. These tasks were incorporated into pharmacists' multiple duties. For example, in 1941, the pharmacists responsible for the medical school and fraud control services in AOF also worked on the extraction of an anti-diarrheic alkaloid from Holarrhena africana to replace emetine, while the pharmacist posted in Niger worked on "Bourgou sugar," and the one in Togo was setting up the production of alcohol from corn. ${ }^{27}$

After World War I, a national bureau, the Office national des matières premières végétales, was created in Paris to oversee the supply of raw plant materials for the French production of medicines, alcohol, chemicals, and perfumes. Pharmacist Emile Perrot directed this bureau as well as the Materia Medica Museum and its laboratory at the Faculty of Pharmacy in Paris. He oversaw a program to inventory plant resources on the scale of the French Empire, analyzed their industrial and therapeutic potential, and proposed their rational

25 According to the pharmacy inspection service in Tonkin, there were at least 1,700 shops selling traditional medicines in 1931, of which 180 were in Hanoi, in contrast with around twenty private pharmacies; "Rapport sanitaire annuel du Tonkin, 1931," Vietnam National Archives, center 1, Hanoi, Fonds de la Résidence Supérieure du Tonkin Nouveau Fonds (RST NF), 3683. In French West Africa, inspections were considerably more lax and covered a much smaller pharmacy market that excluded "traditional" therapeutic transactions.

26 On the ideology, see Albert Sarraut, La Mise en Valeur des Colonies (Paris: Payot, 1923); and on its application, see Alice Conklin, A Mission to Civilize: The Republican Idea of Empire in France and West Africa, 1895-1930 (Stanford: Stanford University Press, 1997). On the relationship between mise en valeur and French colonial science, see Christophe Bonneuil, Des Savants pour l'Empire: La Structuration des Recherches Coloniales au Temps de 'la Mise en Valeur des colonies françaises' 1917-1935 (Paris: Editions de l'ORSTOM, 1991).

27 "Rapport sur le fonctionnement du service de santé de l'AOF pendant l'année 1941," Archives Nationales du Sénégal, Dakar, 2G41-5. 
cultivation according to imperial "utility" and sites of optimal growth and productivity. ${ }^{28}$ The creation of the ORSC in 1943 entailed an institutional separation between colonial and "national" scientific research, and it pursued its work initially in the context of the Second World War. ${ }^{29}$ The research programs of both offices relied on close collaboration between the Faculty of Pharmacy in Paris and local colonial authorities and pharmacists to identify and obtain plant specimens. Colonial pharmacists were sought out for expertise acquired in their local duties, and metropolitan institutions entrusted them with prospecting missions.

Already versatile by profession, the pharmacist in the colonies adopted pursuits such as medicinal plant research by obligation, as part of his official duties to local, federal, and metropolitan colonial authorities. These pursuits also developed on the margins of the more clearly defined responsibilities of pharmacists, who might also engage in medicinal plant research by vocation. Although colonial pharmacists were kept busy, they were probably not supervised very closely. Furthermore, administrative reports indicate they were encouraged to develop personal research projects that fit into the more general search for raw resources, and which fulfilled an ideal image of the pharmacist as first and foremost a scientist. ${ }^{30}$ While Guichard and Kerharo were both officially entrusted with work on indigenous materia medica, it seems clear that their interests developed into personal projects. For example, when his ORSC prospection mission was interrupted in 1947, Kerharo requested permission to extend his presence in West Africa to complete it.

As military officers and functionaries, colonial pharmacists were highly mobile and rotated between posts every two to three years, on average. This movement across a vast and extremely diverse empire further fostered versatility. Conversely, the cultivation of "local" interests and forms of expertise could justify posting extensions, requested by either the administration or pharmacists themselves. ${ }^{31}$ Guichard and Kerharo were initially put to work on

28 Emile Perrot, Dix Années d'Efforts pour la Production de Plantes Médicinales et Aromatiques (Paris: Office National des Matières Premières Végétales, 1929). On Perrot's career, see Christine Debue-Barazer, Des Simples aux Plantes Médicinales: Emile Perrot (1867-1951), Un Pharmagnoste Colonial (Mémoire de DEA en histoire, Université Paris IV-Sorbonne, 2002).

29 Bonneuil, Des Savants pour l'Empire. National scientific research was overseen by the Conseil national de recherche scientifique (CNRS), created in 1939.

${ }^{30}$ For example, the head of the pharmacy services for AOF complained in 1941 that personnel is "insufficient ... a single pharmacist cannot be simultaneously a manager and a chemist, for due to the accumulation of functions, the noble portion of his professional activities is reduced to practically nothing, to the detriment of ... technical excellence" (Archives Nationales du Sénégal, 2G41-5).

31 Unlike doctors, there was never a civil corps for colonial pharmacists. They could be "taken out" of military ranks and "lent" to metropolitan or overseas scientific institutions or to the colonial health services for a limited time. Administrative files suggest three possible reasons for longer-than-usual stays: an administrative request, based on an officers' particular competence or usefulness to the local health service; the detachment of an officer to a colonial research institution, such as an Institut Pasteur; or a personal request by the officer (who might be interested in pursuing a long-term project). 
medicinal plants and "traditional" remedies as part of a mandated mobility between colonies, postings, and undertakings. This work was justified by broader colonial programs of extraction, substitution, and regulation. Yet both their careers also display signs of commitment to specific places and to medicinal plant value, and this problematizes any analysis of their work as purely instrumental.

\section{Trajectories of Expertise and the Colonial Politics of Science}

Framing plant research as part of pharmacists' trajectories allows us to consider how medicinal plant knowledge can take shape within, but also develop at the margins of and move beyond, colonial economic policies, cultural politics, and institutions. This joins Mark Harrison's call, echoing Roy McLeod, to pay attention to the "multiple engagements" of scientists working in colonial contexts, whether in the metropole or colony, as a means of understanding how science can be "woven into the fabric of colonialism" and yet "not defined by colonialism alone." 32 A focus on scientists rather than institutions or policies can reveal surprising openness to vernacular contexts and knowledge, and in some cases such a perspective can foster critical views of colonial rule and knowledge. $^{33}$

In other words, taking individuals' expertise as a point of entry to plant science in the colonies reveals the limits of analyzing colonial science solely in terms of instrumental politics. There is no doubt that the relation between medicinal plant science and colonial power was at least in part an instrumental one: scientists were put at the service of political and economic goals and relied on imperial networks and authority to conduct their work. The bearers of "local knowledge," such as healers, assistants, and informants on whom medicinal plant research relied, were also made into instruments of value extraction. Yet as Nancy Jacobs argues, scientific engagements under colonial rule were also governed by what she calls an "intimate politics." 34 Jacobs draws attention to how intimacy - the affective and embodied engagements between the people and objects implicated in scientific practice - is both a necessary condition of knowledge production and, especially in colonial settings, a source of anxiety about the transgression of boundaries. Jacobs' analysis of ornithological researchers highlights their complex negotiations of colonial and scientific conventions and hierarchies in working with and crediting local assistants.

\footnotetext{
32 Mark Harrison, "Science and the British Empire," Isis 96 (2005): 56-63. Roy MacLeod, "Nature and Empire: Science and the Colonial Enterprise. Introduction," Osiris 15 (2000): 1-13.

33 Helen Tilley, "Global Histories, Vernacular Science, and African Genealogies; or, Is the History of Science Ready for the World?" Isis 101, 1 (2010): 110-19; William Beinart, Karen Brown, and Daniel Gilfoyle, "Experts and Expertise in Colonial Africa Reconsidered: Science and the Interpenetration of Knowledge,” African Affairs 108 (2009): 413-33.

34 Nancy Jacobs, "The Intimate Politics of Ornithology in Colonial Africa," Comparative Studies in Society and History 48, 3 (2006): 564-603.
} 
Following Hugh Raffles, intimacy includes not only the social relations of scientific work, but also the material engagements with landscapes and life through which local knowledge is produced. As it travels, this knowledge is both translated into universal forms and labeled as "merely" local. ${ }^{35}$

While our sources do not allow for extensive analysis of Guichard's and Kerharo's interactions with assistants and informants, or with plants and their parts, we want to draw attention to how trajectories of expertise connect such emplaced material and social relations to the instrumental politics of colonial plant research. We use trajectories to draw into a single frame the circulation of plant matter, of value (scientific and economic), and of scientists themselves, and the ways in which they were rendered mobile through intimate engagements with local biodiversity, informants, and ways of knowing, and also by their circulating in colonial and imperial networks of government and exchange. We demonstrate how what might be called a "circulatory politics" of colonial science can provide an analytical bridge between these entangled processes of (de/re)localization and creation of value.

In Bruno Latour's famous chapter in Pandora's Hope on "Circulating Reference," he analyzes how bits of "the field" are, by acts of tagging, mapping, sampling, and so forth, made to carry information across both space and systems of reference. ${ }^{36}$ Thus, "the local" both loses and retains its connections to the field, increasing its value for knowledge-production and stabilizing its meaning as it moves toward "universal" results of lab analysis and scientific publication. Latour explicitly brackets the "context" (i.e., the postcolonial politics) of one field expedition that involves a French research institute in order to focus on its "content." For us, his observations invite an analysis of politics not just as "context" but also as generative of possibilities for the circulation of "reference" in the work of Guichard and Kerharo. This circulation followed and was facilitated by specific, colonial channels of administration and exchange. It also produced parallel hierarchical relations between types of knowledge (local/universal) and types of spaces (peripheral/central) through which the "colonial local" was controlled and transformed. This circulatory politics was animated by what Latour, in the next chapter of Pandora's Hope, calls the "composite goals" of scientists and politicians or administrators, thus drawing together the mobilizing potential of both "obligation" and "vocation.",37

By examining Guichard's and Kerharo's "trajectories of expertise" side by side, we illuminate contrasting approaches to "indigenous pharmacopeias" in

35 Raffles, "Intimate Knowledge."

${ }^{36}$ Bruno Latour, "Circulating Reference: Sampling the Soil in the Amazon Forest," in Pandora's Hope: Essays on the Reality of Science Studies (Cambridge: Harvard University Press, 1999), 24-79.

${ }^{37}$ Bruno Latour, "Science's Blood Flow: An Example from Joliot's Scientific Intelligence," in Pandora's Hope, 80-112. 
two colonial settings. Yet a straightforward comparison is precluded by differences in the foci of their work (Guichard on laboratory analysis, Kerharo on botanical and ethno-pharmacological field surveys) and its timing (Guichard worked on medicinal plants in Indochina from the 1920 s to the 1940s, Kerharo in West Africa from the mid-1940s to the late 1970s). Nevertheless, they tell us more together than apart about colonial scientists' potentially creative and idiosyncratic responses to, but also their inability to escape, the political and economic contexts for their work. Focusing on professional trajectories creates pathways across colonial archives, biographical files, and scientific publications. This draws out interesting connections, in particular between expressions of need, obligation, and curiosity in pharmacists' work, but it does not allow for detailed reconstructions of their lives and careers. Guichard's work is illuminated by archival sources on the materia medica laboratory he directed, but especially by his numerous scientific publications. Yet we have almost no information on the final years of his career. Kerharo, too, published prolifically, including programmatic statements about his research in the 1960s and 1970s. We have also gained access to his extensive professional correspondence and his former colleagues from these decades through the university laboratory he created in Dakar (now in Cheikh Anta Diop University). ${ }^{38}$

\section{FRANCK GUICHARD, A PHARMACOLOGIST IN SITU}

Initially posted in Gabon after his graduation from the Bordeaux Faculty of Pharmacy in 1922, Guichard traveled to Cambodia, Cameroun, and Vietnam, interspersed with postings in Bordeaux and Marseille. He directed laboratories of chemistry, hygiene, and fraud control, provided expertise to the colonial services at the port of Bordeaux, and taught at the Pharo school in Marseille and the Faculty of Medicine of Saigon. Amidst this diversity in places and functions, three postings in Indochina stand out. From 1926 to 1929, Guichard was "lent" to the Chemistry Laboratory of Phnom Penh, where he worked on krabao oil as a leprosy therapy extracted from a local plant (Hydnocarpus anthelmintica). It is likely as a result of his growing interest in materia medica that Guichard requested an extension of his stay in Vietnam, which lasted from 1934 to 1942. In the colonial capital of Hanoi, Guichard directed the central supply pharmacy of the indigenous health service (Assistance médicale indigène) for the protectorate of Tonkin. Soon he took on additional

\footnotetext{
38 Both pharmacists have slim biographical files at the Bibliothèque Inter Universitaire de Pharmacie at the Faculty of Pharmacy in Paris. Information on Guichard's career is also drawn from his personal file kept by the Army Historical Service in Vincennes (GR 15 Yd 1032). Archived colonial reports contain little information about pharmacists, but following individuals allowed us to connect them to institutional reports and scientific publications. The latter proved a rich source of information about collaborative networks, the practices through which they acquired and transformed knowledge about plants, and, to some extent, the imagined patrons, audiences, and beneficiaries of their work.
} 
functions, first as director of the fraud control laboratory, and then, in 1939, as chair of pharmacology and materia medica at the Faculty of Medicine and Pharmacy and director of the newly created Laboratory for the Study of Indochinese Materia Medica. He left Vietnam in 1942, but then returned to Saigon in 1945, likely of his own volition and as a civilian since he left active service that same year. He stayed until 1949, teaching materia medica and applied physics at the new Faculty of Medicine of Saigon. ${ }^{39}$

Guichard participated in colonial efforts to define certain indigenous therapies as dangerous, to control them and to render them economically useful for French colonialists, but his interest in "utility" was broader than that. Apparently sparked by growing awareness of the extraordinary potential of Indochina's biodiversity, he focused on possibilities of local plant-based industries and on improving the quality and safety of their products. Guichard's work was primarily pharmacological and lab-based. From his lab, he made possible both imperial and national trajectories of intensification and consumption of value that sometimes bypassed the metropole. How, as a pharmacologist in situ, did Guichard shape understandings of Vietnamese medicinal plants and therapies?

\section{An Empire of Utilities}

Like many colonial pharmacists, agronomists, and botanists, Guichard was invested in the acclimatization and optimization of plant crops and species in the colonies to "compensate" for their impossible or difficult acclimatization in the metropole, or to bypass costly foreign monopolies. While in Hanoi, for example, he worked on Hymenodictyon excelsum velutinum (HEV), ${ }^{40}$ a tree that had just been "rediscovered" in 1936 by botanist Eugène Poilane. Sometimes called Asian cinchona, it grew easily in some areas of northern Vietnam. Guichard refined its botanical study and evaluated its chemical and pharmacological potential. This endeavor was seen as crucial at a time when trials of cinchona cultivation in Indochina - in the hopes of breaking the Dutch monopoly on supplies of raw materials for quinine productionseemed increasingly likely to fail.

A running theme in Guichard's scientific publications from the 19201940s is his fascination with indigenous plants identified as potentially "very useful." Such superlative utility stemmed from a product's ability to serve the empire as a whole. His conception of empire was marked by a quasi-fusion of metropole and colonies in which benefits were shared. This vision was common to other imperial plant projects at the time, such as Perrot's, but the

\footnotetext{
39 Guichard's retirement from the military in 1945 might explain the lack of documentation about the last part of his career.

40 Bernard Joyeux, Franck Guichard, and Eugène Poilane, "L'Hymenodictyon Excelsum Velutinum au Tonkin," Annales de Médecine et de Pharmacie Coloniales 35 (1937): 234-48, 997-98.
} 
"empire of utilities" that Guichard conjured in his lab stood out in two ways. First, he located analysis in the colonial laboratory, thereby making and circulating value without necessarily going through metropolitan labs (or botanical gardens). Second, he differentiated this value as it circulated through the diverse geographical and social spaces of the empire. He often described how the value added by scientific intervention (isolation of active compounds, experimentation in specific uses) was modulated by differing capacities and needs, making plants rich and versatile sources of utility.

Guichard seemed especially interested in what might be described as "modern panaceas," products able to treat an extensive range of diseases and symptoms, and often also serve additional purposes in the food industry, agriculture, or cosmetics. We see signs of this interest in the early 1930s when Guichard worked in Douala, Cameroun. He sought to improve an industrial process for discoloring palm oil obtained from a tree growing abundantly in the region. ${ }^{41}$ His objective was to increase its export value on an international scale, creating additional value for both the metropole and for Cameroun, and even the empire as a whole. The oil was used primarily in industrial soap production, but Guichard sought to explore additional possibilities: as a base for fish canning (an industry with promise for both production and consumption on local and regional scales); as an alternative to olive oil in the preparation, in accordance with Codex instructions, of some injectable therapeutic products; and use of its by-products as an ingredient in potassium-based substitutes for "black soap" used to treat skin conditions in Cameroun. ${ }^{42}$ Making maximal use of a single substance, Guichard sought to extend its benefits, albeit modulated, for "all."

At various points in his career Guichard also turned his attention to fishing poisons (ichthyotoxic plants) in hopes of transforming them into human remedies, thus crossing a boundary that only a pharmacologist could transgress. ${ }^{43}$ Having observed local uses of such poisons in Vietnam and Laos as insecticides for dog ticks, he hypothesized that plants such as those of the Derris family, found to contain rotenone, might be used against human parasites such as those causing ankylostomiasis, a common condition in Indochina. ${ }^{44}$ Trials, first on rabbits and then humans, with Guichard subjecting himself to experiments before enrolling patients of the Nam Dinh hospital (Tonkin), gave

41 Franck Guichard and C. Aubert, “Contribution à l'Etude de la Décoloration des Huiles de Palme: Application à 1'Amélioration du Procédé Indigène de Préparation de ces Huiles," Annales de Médecine et de Pharmacie Coloniales 30 (1932): 34-59, 280-91.

42 Ibid., 56. It appears that this research was oriented by Guichard's own choice of product and objectives.

43 Guichard wrote at least eight other articles on this topic between 1936 and 1960.

44 Rotenone was isolated by a Japanese chemist in 1902. In the 1920s, it was already being used as an insecticide powder worldwide. Thousands of tons were produced using plants from Brazil, Peru, Belgian Congo, Dutch East Indies, and French Equatorial Africa. It was replaced by DDT during World War II. 
equivocal results, including several cases of toxic side-effects. ${ }^{45}$ As in his work on palm oil, this trial of rotenone sought not only to optimize the value and uses of an exportable substance, but also to reduce the costs of colonial health services by creating accessible and affordable commodities. Yet he also insisted on the need for safety and quality, attending to the economic interests of the colonial services to which he was accountable, but also the welfare of colonized populations. $^{46}$

Most of the medicinal plants Guichard studied in Vietnam had multiple indigenous uses and thus already qualified locally as panaceas. HEV bark, for example, was used not only for fever but also as a general tonic. ${ }^{47}$ This was also the case of cajeput oil, extracted from a tree growing abundantly across Southeast Asia and used to treat a variety of ailments such as "rheumatism, gout, paralysis, epilepsy, toothache." ${ }^{48}$ Guichard analyzed cajeput oil in 1937 and found high concentrations of eucalyptol, known for its antiseptic properties. He then sought to broaden its uses and for three months experimented with the treatment of surgical wounds, burns, and infected injuries. This time the trial's outcome was hailed as a success, and the product as safe and effective. Cajeput oil was half the price of iodine, which was at the time the most common antiseptic used in Indochina.

To select plants for analysis, Guichard drew mostly on well-known colonial botanical inventories ${ }^{49}$ and also, from time to time, on personal interaction with local healers and druggists such as Phó Đức Thành, a renown "traditional" druggist from the city of Vinh (Annam), whom he acknowledges on several occasions. He also met with vendors in local markets where plants and remedies were sold (this is how he got his information about the use of Derris plants as insecticides, for instance). Thus, he was curious about and perhaps even respectful of indigenous practices. He also seemed attentive not only to the economic and geographic accessibility of potential products, but sometimes also to their local acceptability. Guichard was simultaneously the bearer of a broader project of mise en valeur and concerned with the safety, efficacy, and accessibility of therapies for local populations. In this quest, he extracted what he

\footnotetext{
45 Guichard nevertheless retained the ambition of making fishing poisons into "very useful" products (Kerharo, Guichard, and Bouquet, "Les Végétaux," 313).

46 Guichard might have been interested in these plants as a potential alternative to santonine, an effective but also toxic product widely used against worms.

47 Joyeux, Guichard, and Poilane, "L'Hymenodictyon," 245-46.

48 Cajeput oil was also traditionally used to make torches and to seal fermentation jars, and reportedly was already exported to France as a solvent for rubber; Franck Guichard and Pierre Huard, "Utilisation Chirurgicale de l'Essence de Cajeput," Annales de Médecine et de Pharmacie Coloniales 35 (1937): 935.

${ }^{49}$ He cites often Emile Perrot and Paul Hurrier's Matière Médicale et la Pharmacopée Sino-annamites (Paris: Vigot, 1907); Paul H. Leconte's La Flore Générale de l'Indochine (Paris: Masson, 1907-1942); and Charles Crévost's Catalogue des Produits de l'Indochine (Hanoi: Imprimerie d'Extrême-Orient, 1917-1941).
} 
called "Indochinese" medicinal plants from their original therapeutic systems to reveal their therapeutic value by chemical analysis in the lab, to be followed by "judicious therapeutic trials." $\mathrm{He}$ operated a sort of metonymic association between pharmacologically active compounds (such as eucalyptol or rotenone) and the plants containing them. Active compounds defined plant value and became reference points for any classification or search for therapeutic utility. Plants' status in traditional therapeutic formula, preparation, and local history were points of departure for broadening or reorienting their uses and utility. It is notable that Guichard's publications never mention local recipes or preparations of these "valuable" indigenous plants, although he almost systematically mentions their vernacular names.

\section{Sifting the Pharmacopeia}

Guichard was enlisted in a different kind of project as the first director of the Laboratory for the Study of Indochinese Materia Medica at the Faculty of Medicine and Pharmacy in Hanoi. This appointment derived from his existing functions as head of the fraud control lab and professor of pharmacognosy. The lab was created as part of an ongoing drive to tighten the regulation of local medical traditions, which colonial health professionals viewed as too empiric and too toxic, as well as a source of competition. The project was ambitious and difficult to implement. Traditional practitioners were numerous, heterogeneous, and mobile, while administrators' knowledge of "Sino-Vietnamese" medicine was limited by their own arrogance and lack of linguistic expertise, and also by indigenous systems' complexity. Metropolitan laws on toxics, transferred to Indochina, were ill-adapted and largely ineffective in these contexts. ${ }^{51}$ Initially planned in 1931, the lab was opened later, through the support of Dr. Heckenroth, the director of health for Indochina, and Dr. Terrisse, who in 1935 launched an innovative rural program as local director of health in Annam to support the "enlightened" integration of "traditional medicine" in the provision of essential healthcare. The population was also demanding improved accessibility, in a context of increasingly radical nationalism. ${ }^{52}$

The laboratory's mission was threefold: to create a systematic inventory of local medicinal plants; to select, by proving its safety and efficacy, plant matter that was "useful" in the sense of having been proven in the lab to be effective and non-toxic; and to transform such plants into usable and accessible

\footnotetext{
50 "Direction locale de la santé, rapport annuel, 1936," Archives Nationales d'Outre-mer, RST NF 3686.

51 See notes 20 and 25. A large number of local remedies used substances that were defined as toxic by colonial law. Thus their dispensation was restricted to state-qualified healthcare professionals.

52 "Organisation de l'Assistance rurale en Annam, 1935-1937," Vietnam National Archives, Center 2, Ho Chi Minh City, Fonds de la Résidence Supérieure d'Annam (RSA), 3362.
} 
pharmaceutical products. ${ }^{53}$ This triple mission was in line with Guichard's conviction that the local population needed to be protected from empirical, toxic remedies. This idea had probably been reinforced by his experience at the Tonkin fraud control laboratory, where "indigenous remedies" were frequently brought in for toxicological analysis, and more broadly by his longstanding preoccupation with scientific improvement for indigenous wellbeing. ${ }^{54}$ Yet we can see in his work a shift from analyzing isolated plants to systematically surveying local therapeutic resources. There was, of course, a selective process at work here; Guichard was still separating plants from local remedies and from the traditional (Viêt, Lao, Khmer, Chinese, etc.) pharmacopeias they were part of in order to keep only those deemed non-toxic. This double "extraction" prefigured a denatured and inoffensive therapeutic system that can only be defined as complementary. Yet there was also a systematic approach that took as its object a therapeutic system as a whole and led to its reinvention on the basis of criteria defined as modern, objective, and scientific. A "Sino-Vietnamese pharmacopeia" course, taught by Guichard himself, had just become a requirement for all pharmacy students in Hanoi.

It is difficult to evaluate Guichard's concrete accomplishments as director of this laboratory. He continued to provide little information on the criteria used to select plants for analysis. Many were seen as panaceas and used as such by the local population. Some, but not all, were already well-known botanically. Tests identified a few as promising, but there is no trace of their insertion into any kind of inventory. Very soon after the lab's creation, its work was at least partly reoriented by the economic imperatives of World War II and the Japanese occupation of the colony from late $1940 .^{55}$ From 1939, the lab was equipped with botanical gardens occupying an area of 8,600 square feet, in part to support the botanical exercises of pharmacy students, but also to make more specimens available for study and "the greatest possible number of plants useful for food, industry, and materia medica, both European and East-Asian." the benefit of the empire as a whole, an endeavor that postponed the study of the "intrinsic value" of traditional pharmacopeias. During this time,

\footnotetext{
53 Archives Nationales d'Outre-mer, RST NF 3686; and Fonds du Gouvernement général de l'Indochine (Gougal), 17172; and Gougal SE C49 c 2(2).

54 Franck Guichard, "La Matière Médicale Indochinoise," in Recueil des Notices Rédigées à l'Occasion du 10e Congrès de la Far Eastern Association for Tropical Medicine (Hanoi: Taupin, 1938), 600-6; “Observations sur Quelques Expertises et Recherches Toxicologiques Effectuées en Indochine,” Annales Pharmaceutiques Françaises 7 (1949): 615-19.

55 Despite commercial agreements signed by the governments of Indochina and Japan from 1940 , it would soon become impossible for the colony to import needed pharmaceutical raw materials and products. A. Bigot and R-F. Auriol, "Le Problème des Médicaments en Indochine de 1940 à 1945," Produits Pharmaceutiques 2, 3 (1947): 109.

56 Franck Guichard, "Création d'un Jardin de Botanique Médicale," Annales de l'Ecole de Médecine et de Pharmacie de Hanoi 5 (1941): 137.
} 
Guichard published on the search for carotene and the analysis of a vegetable oil (both extracted from a common fruit, quả gấc in Vietnamese, or Momordica cochinchinensis) with potential uses in the manufacture of paint and varnish, and the study of saponins molecules in fishing poisons that might be used to make detergents. 57

JOSEPH KERHARO, PROSPECTOR BY VOCATION

Initially posted in French Guyana in 1934, Kerharo was, in the late 1930s, sent to Niger in AOF, then Madagascar, and back to AOF, in Dakar. In these postings he headed various types of labs (chemistry, bacteriology, fraud control) and supply pharmacies, and lectured in the medical and pharmacy schools in Tananarive and Dakar. Interspersed with these overseas military postings, Kerharo was attached to the Pharo to conduct and oversee research, to the Institut Pasteur in Paris to work on penicillin cultivation, and to the ORSC for a medicinal plant prospecting mission in AOF in 1945. Posted as head of a military laboratory in Dakar in 1956, Kerharo stayed as a lecturer in materia medica and then in pharmacognosy at the University of Dakar for over twenty years, remaining beyond the end of his rotation, Senegal's independence, and his retirement from the military.

In an otherwise terse biographical notice, Georges Dilleman declares that Kerharo "found his true vocation" as head of the ORSC mission. ${ }^{58}$ For sociologist Gaël Bordet, Kerharo pioneered an approach to the study of traditional therapies by distancing himself from colonial society and immersing himself in new "systems of value, traditions, ways of being and doing..." Through a process of "intellectual repositioning," Kerharo became the "privileged interlocutor ... of traditional healers" first "by necessity then by choice." Bordet wrote that Kerharo's "discovery of the bush" dated to when, while at his post in Niger, the governor general of AOF entrusted him with a mission to seek out local plant-based sources of fuel and alcohol to face wartime shortages. ${ }^{60}$ These depictions of field expeditions as transformative experiences for Kerharo raise questions about how he negotiated different ways of knowing and valuing indigenous plants over the course of a career that moved in and

\footnotetext{
57 Franck Guichard and Dao Si Chu, "Etude Préliminaire des Graines du Momordica Cochinchinensis Spreng," Annales de l'Ecole de Médecine et de Pharmacie de Hanoi 5 (1941): 143-46; Franck Guichard and Bùi Đình Sang, "Contribution à l'Etude de la Sapotoxine du Thea Sasanqua Pierre," idem.: 139-40; "La Matière Colorante du Fruit du Momordica Cochinchinensis Spreng," idem: 141-42; "Contribution à l'Etude de la Saponine de Aesculus Chinensis Bge Enum pl." Annales de l'Ecole de Médecine et de Pharmacie de Hanoi 7 (1942): 145-46.

58 Bibliothèque Inter Universitaire de Pharmacie, dossier biographique Joseph Kerharo.

59 Gaël Bordet, “Joseph Kerharo, Itinéraire d'un Arpenteur: La Naissance de l'Ethnopharmacognosie,” Incursions 4 (2010), http://www.incursions.fr (accessed 10 June 2013).

60 See also the Wikipedia entry on Kerharo: http://fr.wikipedia.org/wiki/Joseph_Kerharo (accessed 10 June 2013).
} 
out of colonial and national scientific institutions, and spanned colonial and post-independence governments in Africa.

\section{Inventories and Extraction}

There is little doubt that the primary aims of the 1945 ORSC prospecting mission were economic. It followed a series of missions to West Africa closely connected to Perrot's laboratory of materia medica at the Faculty of Pharmacy in Paris. Perrot began exploring the medicinal potential of the African flora through his close contacts with the botanist Auguste Chevalier, who between 1898 and 1914 covered 50,000 kilometers of African territory and then undertook his own missions in 1915, 1927-1928, and 19371938. ${ }^{61}$ Perrot was also involved in a prospecting mission the governor general of AOF entrusted to the colonial pharmacist Numa Laffitte in 1935, which was renewed in 1938 but ended in 1940 with Laffitte's death. It was to complete Laffitte's itinerary and pursue his leads that a new prospecting mission was created by the ORSC in 1944 and entrusted to Joseph Kerharo and Armand Bouquet, both also colonial pharmacists. ${ }^{62}$ Their task was to systematically prospect colonial Côte d'Ivoire for indigenous plants with medicinal and other industrially-exploitable properties, and to follow up on promising plants identified by Laffitte such as sorghum stems for paper-making. This mission was of obvious "interest," the ministry of colonies wrote to the governor general of AOF when seeking its support, because it promised "a source of revenues for the colonies but also to supply the metropole with raw materials."63

Kerharo and Bouquet began to learn "prospecting methods" at the Faculty of Pharmacy in Paris, in part by reading Laffitte's archive. ${ }^{64}$ In Côte d'Ivoire, they sectioned the field into a grid and then sought to know each sector's "inhabitants" and its "healers, sorcerers and witch-doctors." Asking them about plants with therapeutic or toxic effects, the prospectors collected information about names, uses, and location and also gathered herbarium samples. In this initial stage, "all was noted, without classification." With guidance from metropolitan lab-based pharmacists officially connected to the mission by the

\footnotetext{
61 Christophe Bonneuil, “Auguste Chevalier, Savant Colonial: Entre Science et Empire, Entre Botanique et Agronomie," in Patrick Petitjean, ed., Les Sciences hors d'Occident au 20ème Siècle (Paris: ORSTOM, 1996), 15-35; Émile Perrot, "Une Mission en Afrique Equatoriale et Occidentale," Extrait de l'Afrique Française (1915): 1-15; Sur les Productions Végétales Indigènes ou Cultivées de l'Afrique Occidentale Française (Lons-Le-Saulnier: Declume, 1929); Où en est l'Afrique Occidentale Française? Mission en Côte d'Ivoire, Haute-Guinée, Soudan, Sénégal (Paris: Larose, 1939).

62 Bouquet would continue collaborating with Kerharo. He is also the third author of a paper co-authored with Kerharo and Guichard and published in 1960.

${ }^{63}$ Ministre des colonies au Gouverneur général de l'AOF, Paris, 5 décembre 1944," Archives Nationales du Sénégal,1H119 (63).

64 Ibid.
} 
ORSC (including René Paris, Perrot's successor at the Faculty of Pharmacy in Paris), as well as additional data from published sources and follow-up field visits, they sought to determine a "scale of values." 65 Thus the prospectors' judgment was limited to a relative ranking of plants and informed by labs, most of them located in imperial metropoles. By the end of 1947, Kerharo and Bouquet had covered 12,500 miles over three hundred days; collected 1,257 herbarium specimens, 6,000 vernacular names, 950 botanical identifications; and sent eighty samples off to the Paris labs amounting to nearly 2,000 pounds of plant parts. ${ }^{66}$ They filled a dozen types of notebooks and index cards with scientific and vernacular names, field observations, therapeutic indications, and bibliographic references. These provided "tags" for the plants to be classified and selected for further analysis, but also to accompany those traveling to labs and, if needed, to again locate their source in African "nature." The aim was to mobilize plants to create value elsewhere. Yet to attain optimal mobility samples needed to travel with a minimal amount of "local" information. ${ }^{67}$

After three years in the field in Côte d'Ivoire Kerharo spent time in Marseille and Madagascar, but he later returned to West Africa. By the late 1950s, now as a faculty member of the University of Dakar, he began making field trips around Senegal. He published some of his observations by region or ethnic grouping in article-length publications, and then on a national scale as a thesis defended in 1971 and then as a book, his magnum opus, the Pharmacopée Sénégalaise Traditionnelle. ${ }^{68}$ The methods he practiced and advocated into the 1970 s remained strikingly similar to those he had used in the mid-1940s. ${ }^{69}$ For Kerharo, a systematic "ethnobotanical" inventory was the prerequisite for any program of study of medicinal plants, and should guide subsequent analytical and experimental work. Kerharo saw the latter as essential to the arbitration of therapeutic and economic values. Yet he continued

65 Joseph Kerharo and Armand Bouquet, "Sur Quatre Diospyros Africains Utilisés dans la Pharmacopée Indigène de la Côte d'Ivoire (Haute-Volta)," Revue Internationale de Botanique Appliquée 29 (1949): 601-5. Paris also analyzed plants from the Laffitte mission; René-Raymond Hélène Moyse Paris and Marie-Louise Paris, "Le Musée de Matière Médicale de la Faculté de Pharmacie de Paris," Revue d'Histoire de la Pharmacie 63 (1975): 299-306; "Pharmacopée indigène en AOF: Mission Kerharo-Bouquet. Rapport d'activité pour 1947," Archives Nationales du Sénégal, 1 H119 (63).

66 Ibid.

67 Latour, "Circulating Reference."

68 Joseph Kerharo, Recherches Ethnopharmacognosiques sur les Plantes Médicinales et Toxiques de la Pharmacopée Sénégalaise Traditionnelle (Thèse de doctorat, Faculté de médecine et de pharmacie, Université Cheikh Anta Diop, Dakar, 1971); Joseph Kerharo and Jacques G. Adam, La Pharmacopée Sénégalaise Traditionnelle: Plantes Médicinales et Toxiques (Paris: Vigot Frères, 1974).

69 Joseph Kerharo, “L'Inventaire Ethnobotanique Systématique des Plantes Médicinales et Toxiques, Point de Départ de Toute Etude sur les Médecines et Pharmacopées Africaines Traditionnelles," Colloque du CAMES sur la pharmacopée et la médecine africaines traditionnelles, Lome, 19-22 Nov. 1974. 
to locate his own expertise in the field (though partly, he explained in a letter, because of the lack of equipment and space in his university laboratory). ${ }^{70}$

Methodological continuity was paralleled by continuity in the geographical circuits of plant matter. In 1965 Kerharo sketched out a program for the "study and exploitation of Black African medicinal plant resources" at the Faculty of Medicine's annual symposium. He divided lab and clinical research from field-based work, suggesting that only the latter-concerning the study and cultivation of plants as raw materials - was necessarily "African," by which he meant "local."71 Analysis and evaluation, he suggested, could be elsewhere (i.e., remain in the former metropoles). He encouraged a free exchange of samples with any interested researcher and indeed his correspondence reveals that he reinitiated, from Senegal, a lively traffic in plant matter with several labs, most of them in French faculties of pharmacy including in Paris. Yet Kerharo did relocate the ultimate benefits of medicinal plant research in "Africa," now defined as a space of sovereign nations, and he supported the creation of inter-African networks on medicinal plants in association with a more general program of exploration of plants for industrial or commercial prospects. $^{72}$

From the mid-1970s, Kerharo lobbied more actively for the creation of a national institute to "exploit" indigenous medicinal plants and knowledge: the Institut sénégalais de recherches pour l'étude et l'exploitation de la médecine et la pharmacopée africaines. ${ }^{73}$ He seized the opportunities offered by a special fund created in 1975 by a new ministerial agency for science and technology to "energize" scientific research. ${ }^{74}$ Of the first budget of 50 million CFA francs (XOF), 16 million were earmarked for "pharmacopeia" equipment (for chromatography, spectrophotometry, etc.). In January of 1978, the creation of a "pharmacopeia institute" was announced, but the next installment had not yet been "written into the budget." Given "particular importance" in funding

70 "Kerharo to Dr. Patel, Khartoum, 28 January 1965." Orders, bills, receipts, and inventories show that his lab was equipped in the 1960s mainly with materials for preparing plant samples (grinders, evaporators, etc.). Unclassified archives of the Laboratoire de matière médicale et de phamacognosie, Université Cheikh Anta Diop, Dakar.

71 Joseph Kerharo, “Esquisse d'un Programme d'Etude et d'Exploitation des Ressources de l'Afrique Noire en Plantes Médicinales: Reproduit d'une Communication aux 4e Journées Médicales de Dakar, 4-12 janvier 1965," Bulletin et Memoires de L'ecole Nationale de Medecine et de Pharmacie de Dakar 13 (1965): 212-16.

72 Ibid.

73 This project was submitted to the Direction générale de la recherche scientifique et technologique in 1975 ("Kerharo to J.-P. Guengant, 9 January 1975," unclassified archives of the Laboratoire de matière médicale et de phamacognosie, Université Cheikh Anta Diop, Dakar). No copies were found among his correspondence.

74 This fund was allocated by the Direction générale de la recherche scientifique et technologique that was created in 1973 to prioritize science and technology in development planning; "Quatre Années de Fonctionnement de la Délégation Générale à la Recherche Scientifique et Technique: Le Point sur la Politique Scientifique et Technique du Sénégal et les Perspectives de son Evolution" (Dakar: République du Sénégal, 1978). 
priorities was research likely to reduce the costs of healthcare (as had been the case during the colonial period) and thereby make accessible the "right to health" (a postcolonial concern). ${ }^{75}$

In the 1960s, Kerharo had proposed the study of medicinal plants as a path to drug discovery and commercial applications for the benefit of "Africans." By the mid-1970s, he was writing of a new "African path" along which "exploitation" now meant "renovation" of indigenous pharmacopeias. A "renovated African phyto-therapy" would lead to therapeutic uses of local plants that were more rational (i.e., effective and safe), and would also serve as a foundation for better public health in a particular "socio-economic context" (i.e., that of slow economic development), as well as stimulate industrial cultivation of medicinal plants. He did not give up the prospect of discovery, but warned that its technical requirements were high-involving purification and analysis of active ingredients at the molecular level-and its yields were low. ${ }^{76}$ In contrast, the "African path" could proceed with mechanical operations and chemical extractions of "active fractions" (more active than the whole plant, but at a supra-molecular level). In terms of "Africanizing" the study of medicinal plants, this sequence of chemical/industrial "exploitation," and the proposed institute, went a step further than Kerharo's earlier suggestions. Africanization now meant nationalizing the territory of local knowledge, of funding, and of concerns about healthcare costs, but it also meant anchoring a larger program in a pan-African imaginary and networks of collaboration. In the end, the planned institute never materialized, and Kerharo is now remembered at the university as a colonial-style prospector who did little to "exploit" the pharmacopeia for the benefit of local people. ${ }^{77}$

\section{Locating Tradition}

Kerharo's writings provide little in the way of detailed description of his interactions with local healers, but they do attribute two functions to these healers' knowledge: to guide the production of pharmacopeias, and to provide a window onto African societies. In the first case, healers' knowledge and the study of it were integrated into the methods of ethnobotanical prospecting; as Laffitte had written, it offered a "shortcut" to identifying potentially active plants. ${ }^{78}$ This is how "local knowledge" was built into the prospecting

${ }^{75}$ Ibid.

76 Joseph Kerharo, "La Recherche de Médicaments Nouveaux dans le Cadre de l'Etude et de l'Exploitation de la Pharmacopée Africaine Traditionnelle," Bulletin et Mémoires de l'Ecole Nationale de Médecine et de Pharmacie de Dakar 24 (1976): 82.

77 The last-planned Fonds d'impulsion pour la recherche scientifique et technique budget was likely cut or eliminated due to cuts in public spending at the end of the 1970s brought on by the effects of the oil crisis, drought, dropping global commodity prices, and the conditions attached to loans by the International Monetary Fund.

${ }^{78}$ Numa Laffitte, Missions du Pharmacien-Colonel Laffitte (Paris: ORSC, 1946). Bouquet and Kerharo helped edit these documents after Laffitte died, and read them in Paris as they were 
methods of the Laffitte and Kerharo-Bouquet missions. Colonial medical administrators worried when local judgments of efficacy were not fully absorbed into a scientific process of evaluation. For example, in 1947, the director of public health for AOF chided Kerharo for submitting a paper, without administrative approval, that recommended, but contained no results of, clinical and laboratory evaluation to verify the assertions of an eye-healer and his six formerly blind patients concerning the effects of a plant-based treatment. ${ }^{79}$

Still, Kerharo refrained from attributing any evaluative function to healers' knowledge. Throughout his career, he linked the value of fieldwork to lab and clinical tests. Yet in the 1960 s, we can discern in his work a shift from a sequential progression in, to an entanglement of, the steps from ethnographic to experimental investigation. Kerharo made it clear that "local knowledge" and its ethnographic description did not become dispensable when plants had moved into the lab. Detailed observations of healers' knowledge and methods not only increased the reliability of botanical identification and location (which could affect composition and potency), but also provided essential information about the content and alteration of plant substances. Kerharo told the Congress of Africanists in 1967: "We often forget that the analysis of such preparations will not allow even the most skilled chemist ... to determine the identity of the vegetal matter and much less of the plant organs used." "The surest way to [obtain this knowledge]," he continued, "is to re-live with the therapist, in a sort of psychodrama, the different acts leading to obtaining ... the powder ... starting from the collection of plants." $\$ 80$

Still, in the process of producing plant inventories for pharmacological discovery, healers' knowledge was absorbed into the attribution of an "order of values" in the classification of the plants' uses and potentials. In another, more ethnographic genre, Kerharo and his co-authors wrote about healing practices as elements of local culture that were interesting in their own right. Yet throughout his career Kerharo carefully kept ethnographic and inventory writing separated as distinct genres. The results of the ORSC mission were published in two books in 1950, one an inventory of medicinal and toxic plants, the second a treatise on "sorcerers, witch-doctors, and healers."

preparing their own mission in 1944. On the function given to healers as a "screening" for value, see Langwick, "Healers and Scientists."

79 "Directeur Général de la Santé Publique AOF to Directeur Local de la Santé Publique, Côte d'Ivoire, 24 March 1948," Archives Nationales du Sénégal, 1H119(63).

${ }^{80}$ Joseph Kerharo, "Pharmacopées Africaines Traditionnelles et Recherche Scientifique," Congrès International des Africanistes, Dakar, 11-20 Dec. 1967 (Paris: Présence Africaine, 1972), 479; Kerharo and Adam, Pharmacopée, 12-13.

${ }^{81}$ Joseph Kerharo and Armand Bouquet, Plantes Médicinales et Toxiques de la Côte d'Ivoire-Haute-Volta: Mission d'Etude de la Pharmacopée Indigène en AOF (Paris: Vigot Frères, 1950); Sorciers, Féticheurs et Guérisseurs de la Côte d'Ivoire- Haute-Volta (Paris: Vigot Frères, 1950). A reviewer criticized the latter for its "naiveté," and indeed in 1967 Kerharo 
Kerharo continued to publish separately on plants as objects of scientific knowledge and on plant-based healing until the 1970s. The structure of his thesis and of the Pharmacopée isolated and subordinated "the magico-religious factor" as a prelude to an inventory of plants, in which entries included local uses as merely suggestive of the potential for analysis and "exploitation." In parallel, Kerharo suggested a historical separation, which he explained on Senegalese national radio in 1964 as one between an initially "empirical, rational, realist" therapy and the "mystical traits [acquired] only afterward." 82

In post-independence Senegal, Kerharo invested new meaning in the ethnographic dimensions of his work. He pointed to its potential to provide "consciousness of their culture and its value to Africans, who thereby contribute their stone to the building of progress and of universal civilization. ${ }^{83}$ Such wording echoed the vocabulary of Kerharo's new audience. "Universal civilization" (or "civilization of the universal") was a key term within the ideology of Négritude that Senegal's first president, Leopold Sédar Senghor, developed into a political philosophy and cultural policy. ${ }^{84}$ Senghor (who wrote the preface to the Pharmacopée) held up Kerharo's work, along with that of others including Henri Collomb's experiments in cross-cultural psychiatry at Dakar's Fann hospital, as expressions of a desirable syncretism between "discursive reason" and "African values." 85 Senghor praised Kerharo for liberating Senegalese medicinal plants from the "folklore in which they were, since the first exploration writings, imprisoned like museum pieces." 86 Yet even Senghor saw the liberation of this cultural therapeutic heritage as having potential economic value for the country's expanding but cash-strapped public health system.

COLONIAL SCIENCE? "THE LOCAL” AND LEGACIES OF PHARMACEU-

TICAL EXPERTISE

Guichard and Kerharo clearly participated in projects to disentangle medicinal plants from local ecologies and societies in order to generate extractable

\footnotetext{
"confessed" to an audience of Africanists that he regretted that neither an ethnologist nor sociologist had been involved ("Pharmacopées Africaines," 481).

82 Joseph Kerharo, “Connaissance de la Pharmacopée Sénégalaise: Conférence Enregistrée à Radio-Sénégal pour 1'Université Radiophonique, Dakar, 1964," Bulletin et Mémoires de l'Ecole Nationale de Médecine et de Pharmacie de Dakar 12 (1964): 230-41.

83 Kerharo, Recherches, 8.

84 Leonard Markovitz, Léopold Sédar Senghor and the Politics of Négritude (New York: Atheneum, 1969); Elizabeth Harney, In Senghor's Shadow: Art, Politics and the Avant-Garde in Senegal, 1960-1995 (Durham: Duke University Press, 2004).

${ }^{85}$ Leopold Sedar Senghor, "Préface," to Kerharo and Adam, Pharmacopée; Alfred Quenum, "Senghor et la Santé du Peuple," Ethiopiques (1976), http://ethiopiques.refer.sn/spip.php? article630 (last accessed 22 June 2015); Niang, Souleymane, "De la Politique Scientifique Senghorienne: Principes et Stratégies," Ethiopiques (1976), http://ethiopiques.refer.sn/spip.php? page=imprimer-article\&id_article $=629$ (last accessed 22 June 2015).

86 Id.
} 
natural resources and governable therapeutic substances. Yet their research also (re)localized plant value in the activities of local government, national healthcare, economic relations, and "cultural" systems. The question of whether and how their work qualifies as "colonial science" turns on both spatial and temporal issues. In this last section, we explore first how these pharmacists' activities encountered were transformed by, and even produced the space of "the local" and its relation to broader imperial geographies. We then turn to the postcolonial legacy of the work they first conducted under colonial administrations.

\section{What Is Local?}

The understandings of indigenous "pharmacopeias" that Guichard took from his work in Indochina and those Kerharo developed from his West Africa research were quite different. In Indochina, and especially in Vietnam, Guichard assumed that there existed a materia medica, a coherent corpus of medicinal plants and preparations held together by therapeutic knowledge, already available to sift, analyze, and rationalize. To select plants for analysis, Guichard drew on botanical inventories, which were numerous and accessible in a language he understood (nothing leads us to believe he was fluent in any "Indochinese" language). The earliest were published during the eighteenth century by European missionaries and doctors who encountered the rich Vietnamese flora, met with local healers, and learned about a long history of scientific and therapeutic exchanges between China and Vietnam. ${ }^{87}$ Although Guichard was interested in "traditional medicine," he, like other colonial scientists, commonly and unquestioningly used the terms "Sino-Vietnamese medicine" and even "Indochinese materia medica." These expressions, especially the latter, reveal ignorance of the complex and extremely varied ecologies and sociocultural histories of the Indochinese peninsula - those of ethnic majorities such as the Viêt, Khmer, and Lao as well as numerous minorities, of the north and the south, the plains and the mountains. They reduced the diversity of therapeutic practices to a single entity defined externally, by Chinese influence or colonial borders. ${ }^{88}$ At the same time, there was no formal Vietnamese medical system at the time, and Vietnamese people themselves used at least two different expressions to talk about "their" medicine: Thuốc bắc, or "northern medicine," to qualify a scholarly medical tradition influenced by Chinese medicine; and Thuốc nam, or "southern medicine," a more popular, purely Vietnamese medical tradition using local plants and remedies. ${ }^{89}$

\footnotetext{
${ }^{87}$ One of the most mentioned is Portuguese Jesuit Joao de Loureiro's Flora Cochinchinensis: Sistens Plantas in Regno Cochinchina Nascentes (Ulyssipone: Typis, et Expensis Academicis 1790).

${ }^{88}$ Guichard focused his research on plants used in Vietnam, but it is unclear whether these were only or mainly used by the Viêt population (the ethnic majority).

${ }^{89}$ Monnais, "Can Traditional Medicine Be (Scientifically) Trustworthy?"
} 
Still, these terms recognized the existence of at least a medical tradition, one in which it was clear-from texts and a lively, highly visible, and specialized trade in medicines - that medicinal plants played a dominant role. This materia medica could guide the search of medicinal plant value, but it was also seen as needing a selective rewriting in the language of scientific proof and control. This would produce it as a pharmacopeia according to the modern, regulative definition: as a controlled and authorized repertory of medicinal ingredients. It would also represent a "reinvention" of medical tradition (which some might call a "disembodiment" or "domestication"). This was not an exclusively colonial project. From the late 1930s, several associations of traditional medical practitioners, including the Viêt Nam Y Dược Hội, lobbied the colonial government for a systematic inventory of local materia medica in order to produce a "modern" therapeutic system, one, that is, based on scientifically proven remedies in the name of rendering it less toxic, more effective, and more accessible.

Unlike Guichard in the Indochinese peninsula, the starting point for Kerharo's work in West Africa was a perceived need to first produce a corpus of medicinal plants, botanical knowledge, and therapeutic techniques attached to a territory. In West Africa, the largely oral, generational, and "esoteric" transmission of therapeutic knowledge made it seem less accessible — and for a long time, less valuable - to colonial scientists and administrators. It seemed more fragmented both spatially and culturally and thus difficult to assemble at larger territorial scales. ${ }^{90}$ The Laffitte and Kerharo-Bouquet missions not only drew on "local knowledge" but also mapped out the "local" in which this knowledge was supposedly anchored. The technique of laying spatial grids for prospecting ensured systematic coverage but also tied medicinal plant identity and properties to specific botanical and ethnic populations (the "ethno-botanical binome"), thereby bundling vegetal matter with locality as ecology, terminology, culture, and techniques. Thus to render West African plants optimally mobile as samples or information, they first had to define (some of) their local relations. At the same time, it was the articulation of prospecting work to metropolitan labs, industries, and classifications, where the "local" could then be partially erased, that gave value to Kerharo's field-based labor and expertise within a broader colonial project and geography of knowledge. This labor had several outputs, including specimens and tags, but the most important was the map that connected mobility to origins: the pharmacopeia, which Kerharo defined as a "commented botanical inventory of all plants used for their medicinal or toxic properties in a given region and collation of given verbal information." 91 As we descried earlier, the pharmacopeia as a

90 Kerharo, "Pharmacopées," 476. 
text both absorbed and marginalized the "ethnographic local" in producing locality and mobility.

Kerharo's prospecting in Côte d'Ivoire and Senegal was, until the 1970s, defined in relation to labs elsewhere, mainly in France. By contrast, Guichard worked as a pharmacologist from labs located in the colonies, which were important spaces for the analysis and transformation of plants, but also for the formation and transmission of his expertise. Guichard saw active plant extracts and compounds as his main outputs, as the potential basis of small-scale colonial industries and more economic and self-sufficient colonial healthcare. Useful products were defined as safe and effective but also, and importantly, as versatile and essential. If the former criteria were easily universalized, the latter defined substances' value in terms of local, historically specific needs and uses. We have seen that versatility often originated in reports of multiple indigenous uses while essential products and medicines were usually defined according to colonial administrative healthcare priorities and concerns about accessibility, shaped largely by the prospect and reality of (wartime) shortages and to some extent the demands of colonized populations. ${ }^{92}$

\section{Postcolonial Legacies}

Kerharo's colonial and post-independence medicinal plant prospecting produced "the local" in remarkably similar ways. In both he maintained similar networks of exchange: passing through local administrators to gain access to "reputable" healers, sending reports and reprints to governmental authorities, and trading in plant matter with lab scientists in the former metropole. Despite the adoption of new rhetoric to describe medicinal plant knowledge as cultural heritage, he continued to segregate this local knowledge from the process of attributing value. His main output remained pharmacopeia. Yet he made new claims for field-based expertise in promoting the value and versatility of pharmacopeia as guides for medicinal plant science that subtly repositioned the local in larger geographies of medicinal plant science.

Into the 1970s, Kerharo defended the importance of the systematic inventory as an "often minimized, even ignored" tool of medicinal plant science. In doing this, he emphasized the quality and utility of his field-based collecting and classifying work. ${ }^{93} \mathrm{He}$ also made pharmacopeia more relevant by pointing to multiple possible endpoints: new pharmaceuticals, a rational, renovated therapeutics, or cultural self-knowledge. It was a highly versatile tool and the work of a versatile scientist who was at ease in both the lab and the field, on the lookout for both raw materials and cultural knowledge, and able to enter

\footnotetext{
92 This definition of essential medicines contrasts with the later World Health Organization definition in the context of expanding primary care. See Jeremy Greene, "Making Medicines Essential: The Emergent Centrality of Pharmaceuticals in Global Health," BioSocieties 6 (2011): 10-33.

93 Kerharo, "L'Inventaire."
} 
relations of reciprocal, if not equal, exchange with healers, local administrators, lab scientists, colonial governors, and African presidents. (Kerharo had secured not only Senghor's preface to the Pharmacopée but also the Senegalese government's advance purchase of 180 copies of the book to help finance its publication. ${ }^{94}$ ) In correspondence with scientists who requested plant specimens, Kerharo also invited recognition of the fine-grained botanical, ecological, and ethno-pharmacological knowledge he had accumulated, which was crucial for locating and identifying plants and their potential uses. ${ }^{95}$ By trading samples and reprints and offering up inventories, Kerharo sought to accrue credit as a scientist with "local" expertise in an ex-colony, for whom decolonization had cut off from former pathways of advancement on an imperial scale, and whose colonial past as a military pharmacist had disqualified from metropolitan academic and lab-based scientific prestige. ${ }^{96}$ One of his successors in Dakar suggested that Kerharo stayed after independence because he was unqualified for a university position in France. Be that as it may, his decision paid off: Kerharo's Pharmacopée was given a prize by the prestigious French Academy of Sciences and he was appointed a full professor at the university and promoted from "knight" to "officer" of the order of merit of Senegal.

While Kerharo carried his colonial legacy beyond independence, Guichard's activities shaped the subsequent work of some of his French and Vietnamese co-workers. After Guichard's departure in 1942, shortages of drugs and chemicals in the colony became more acute. A Committee for the Study and Use of Indochinese Drugs was created, followed in 1943 by a council for centralizing, supervising, and orienting research into the production of essential supplies for the chemical and pharmaceutical industries (Conseil des recherches des industries chimiques et pharmaceutiques). ${ }^{97}$ Guichard's successor at the materia medica lab, the colonial pharmacist Pierre Bonnet, was a member of both. Guichard's French colleagues and former Vietnamese assistants, including Bùi Đình Sang, departed from an earlier approach that studied the "Sino-Vietnamese pharmacopeia" as a whole; driven by urgency, they began taking into account traditional recipes and local therapeutic uses of plants as a shortcut to solving shortages (especially in antiseptics and febrifuges) and working on affordable substitutes for medicines such as quinine and emetine. ${ }^{98}$ For example Bonnet, seeking replacements for drugs to treat

94 Grants were also obtained from the French research council (CNRS) and UNESCO.

95 In about 170 letters dating from 1963 to 1976, found in Kerharo's former office in Dakar, about twenty responded to requests for plant specimens. Kerharo also traded in reprints.

96 For an analysis of how "biocolonial" exchanges in specimens secured status, see Warwick Anderson, The Collectors of Lost Souls: Turning Kuru Scientists into Whitemen (Baltimore: Johns Hopkins University Press, 2008).

97 Bigot and Auriol, "Le Problème," 112.

98 "Plantes médicinales. 1. Comité d'études, constitution, réunions, travaux, 1942," Archives Nationales d'Outre-mer, GG SE 2293. 
common ailments such as dysentery, malaria fever, and intestinal worms, offered an inventory of Indochina's diuretic and anthelminthic plants. His classification was ordered by local therapeutic properties, and he suggested they be used according to "simple preparations, akin to those described in the SinoVietnamese pharmacopeia, such as infusions, decoctions, and so forth." In the absence of analytical data on chemical composition, Bonnet deemed it acceptable under emergency conditions to rely on their status in indigenous therapeutics. $^{99}$

Vietnamese-based scientific projects also emerged in parallel to, and sometimes in collaboration with Guichard's work and continued beyond his departure. The career of Bùi Đình Sang is notable in this regard. He first participated in the pursuit of "very useful" substances and modern panaceas while working intensively as an assistant pharmacist with Guichard on quả gấc and saponins. Later qualifying as a full pharmacist, Sang, probably in 1942 while working for Bonnet, was a co-discoverer of a new alkaloid, "Rotundin," in the local flowering plant Stephania rotunda Lour ("discovered" in Cochinchina by de Loureiro in 1790). Sang joined the Communist Party and went underground in $1944 .{ }^{100}$ The antispasmodic and especially the sedative and analgesic properties of Rotundin reportedly helped win the Indochina War, and then the Vietnam War, by relieving nationalist troops. During the long period of decolonization, Sang worked for the Democratic Republic of Vietnam and helped transport medicines and chemicals, cultivated medicinal plants in specific locations, manufactured waterproof bandages, and pursued pharmacological research that included the study of quả gấc and camphor derivatives. Vietnamese historiography later celebrated him as a hero. ${ }^{10}$

Sang's success and versatility as a nationalist scientist are marked by clear continuities between his methods and concerns and those of the colonial period: he continued to emphasize lab methods, the isolation of active substances, and the search for "very useful" plants, even as utility was redefined in the quest for independence and wartime survival. Yet Sang's trajectory departed from his teachers' in at least two ways. First, he traveled throughout the northern part of the Vietnamese territory looking for new useful plants. Before 1945 he was in Bac Giang province researching quả gấc oil, and then in the 1950s he conducted research about camphor products in Thai Nguyen province.

99 Bonnet, Pierre, "Sur l'Utilisation Possible de Quelques Plantes Diurétiques et Anthelminthiques d'Indochine,” Revue Médicale Française d'Extrême-Orient 3 (1942): 469-70.

100 Sang's role in this discovery is unclear, since the director of the lab likely claimed most of the credit for what had been collaborative work. See B. Noyer, Pierre Bonnet, and Bùi Đình Sang, "Etude Préliminaire de l'Action Pharmacodynamique de la 'Rotundine' Alcaloïde Nouveau Retiré du Stephania Rotunda," C.R.S. Conseil de la recherche scientifique de l'Indochine (1943): 61-66.

101 http://suckhoedoisong.vn/20100129102417803p61c89/nhung-chien-cong-cua-mot-duoc-sibinh-di.htm (last accessed 22 June 2015). 
Thus Sang linked the lab-based quest for "very useful" plants with a precise, field-based, and distinctly Vietnamese cartography of their location and potential.

Second, Sang participated in the search for new alkaloids not only for substitution (in the context of wartime shortages), but also for drug development in the context of an expanding world market for pharmaceuticals. In the case of Rotundin, the source plant's geographical origins were less emphasized than the drug's ethnic and political origins (Vietnamese and communist) and Sang's work as its discoverer, analyst, and producer. The history of Rotundin would soon become a focus of fierce competition between Chinese, Soviet, and Vietnamese scientists vying for credit for its discovery. In the early 1960 s, the plant and the alkaloid were quickly inserted into the "Vietnamese" materia medica, Nhũng Cây Thuốc Và Vị Thuốc Việt Nam, a reference work that describes the chemical composition and active ingredients of some 750 species of locally available vegetal, mineral, and animal items with medicinal properties. ${ }^{102}$ And yet this was a "national" rather than a "traditional" materia medica, anchored in a territorial and biological "locality" (and reaffirming its rich biodiversity), but not in a fixed therapeutic heritage. Dynamic and evolving in response to new findings, the compendium ultimately blurred the boundaries between colonial and postcolonial science. ${ }^{103}$

\section{CONCLUSION}

Guichard and Kerharo produced different spaces of medicinal plant research. As a lab pharmacologist in Indochina, Guichard's focused on the destination of purified and active substances, mapping their multiple and multivalent uses in colonial healthcare and metropolitan industry, but also in a modernized materia medica. Kerharo, as a field scientist in West Africa, instead mapped plants' local relations in preparation for their various possible journeys as bearers of economic, therapeutic, and cultural values. In both men's careers, plants were made mobile but were also redefined in ambiguous and selective ways, as local - traditional, colonial, national, or regional-resources and technologies. These processes of de- and re-localization were entangled with the various and potentially contradictory colonial projects in which they participated, but especially important was how Guichard's and Kerharo's trajectories of

102 Đỗ Tất Lợi, Nhũng Cây Thuốc Và Vị Thuốc Việt Nam (Hanoi: Khoa học, 1963). The 2001 edition includes a four-page notice on Cây bình vôi (Stephania rotunda Lour.) that describes the discovery of Rotundin, and mentions Sang, Guichard, and Bonnet (779-82).

103 Research on the alkaloid content of Stephania rotunda Lour. is ongoing, and even the object of collaborative Vietnamese and French research. The alkaloid is also one of the active components of several pharmaceuticals currently produced industrially, distributed, and consumed in Vietnam as "mild herbal" sleeping pills or mild anxiolytics. On the Trasleepy (Traphaco) notice one can read: "Trasleepy with a unique formula combining herbal Rotundin sulfate and nursing care, sedation has been used effectively in Traditional Medicine"; http://www.traphaco.com.vn/san-pham/ trasleepy-vien-thao-duoc (last accessed 17 Dec. 2014). 
expertise contained and connected multiple logics of medicinal plant research: colonial, nationalist, and personal. These were not exceptional trajectories that transgressed firm boundaries between medicinal plant projects. Rather, they expose the fragility of the boundaries involved, and show how space and value are co-produced in multiple and dynamic ways. Guichard's and Kerharo's trajectories also complicate qualifications of science and scientists as "colonial." Still, even if their trajectories could transcend specific political projects, they could never escape (post)colonial fields of power and hierarchy and relations of unequal exchange. Our analysis here illuminates how these fields of power both constrained and facilitated the social and material exchanges that transmitted and transformed knowledge of medicinal plants, while also allowing for the real and varied effects of professional commitment and ambition. Following trajectories of expertise, by eschewing simple equations of scientists' motivations with political projects, allows finer analyses of how colonialisms and their aftermaths shaped scientific activity.

\begin{abstract}
Colonial pharmacists bio-prospected, acclimatized, chemically screened, and tinkered with plants and their parts, hoping to create products to supply colonial public health care, metropolitan industries, and imperial markets. This article's approach is to examine the trajectories of expertise of two French colonial pharmacists, Franck Guichard and Joseph Kerharo, to illuminate the history of modern medicinal plant research. Both men studied medicinal plants as part of their colonial duties, yet their interests in indigenous therapies exceeded and outlived colonial projects. We take this "overflow" as our point of departure to explore how science transformed medicinal plant values in French colonial and postcolonial contexts. Our focus is on the relationship between value and space - on the processes of conceptual and material (de-/ re-)localization through which plant value is calculated, intensified, and distributed. We study and compare these processes in French Indochina and French West Africa where Guichard and Kerharo, respectively, engaged in them most intensively. We show that their engagements with matter, value, knowledge, and mobility defy easy categorizations of medicinal plant science as either extractive or neo-traditionalist. By eschewing simple equations of scientists' motivations with political projects and knowledge-production, we argue that approaching plant medicine through trajectories of expertise opens up grounds for finer analyses of how colonial power and projects, and their legacies, shaped scientific activity.
\end{abstract}

